\title{
Role of corporate governance in attracting foreign investments in Nigeria
}

\author{
Amos N. Dombin \\ Plateau State University, Bokkos, P.M.B 2012, Jos, Plateau State, Nigeria
}

\begin{abstract}
Corporate Governance is a system of financial and other controls in a corporate entity and broadly defines the relationship between the Board of Directors, senior management and shareholders. Globalization and liberalization is sweeping across all sectors of economy with rising problems, risks, challenges more pronounce in developing economies. The position of Nigeria in global Transparency is among top ten from the rear and with continuous rise in the number of business collapsed, only organizations that adopt good Corporate Governance and best practices will survive and attain sustainable growth level locally and internationally in this competitive business environment. This paper examined the concept of Corporate Governance, its background in Nigeria, principles, importance/objectives as well as benefits to the Nigerian economy in terms of local and foreign investments.
\end{abstract}

Keywords: Corporate Governance; Ethical issues; Investment

\section{INTRODUCTION}

Corporate Governance has become the buzzword for corporate culture in Nigeria in recent time. Andrain Cadbary, whose report has become the Bible of corporate governance, defines it as "System or process by which companies are directed and controlled. In other words, corporate governance is about commitment to values and ethical business conduct. It is about how an organization is managed, this includes its corporate and other structure, its culture, policies and the manner in which it deals with various stakeholders. The bedrock of good corporate governance is to conduct the affairs of a company or an organization in such a manner as to ensure fairness to all stakeholders in fulfilling the responsibility that requires quality of leadership, values, transparent management, vision and goals, respect for law and sense of social responsibility.

\section{CONCEPTUAL FRAMEWORK}

Over a period of time, with the fast developments in the world, the widened scope of corporate governance and on the other hand, the slow divergence of the Nigerian monoculture oil based economy has continuously led to public out cried for broad base economy through the development of non oil sector as well as growth in foreign investment. Succession government from independence (Military $\&$ democratic) have introduced various policies all geared towards economic self reliance and additional push (foreign investment) to strengthen 
or evolve sustainable growth and development, but in most cases, these programmes failed to reach their full potentials or achieved their objectives due to absences of corporate governance that is largely manifested in the form of corruption among others. These under achieved programmes range from IBB, Structural Adjustment Programme (SAP) to recent Jonathan administration Direct Foreign Investment (DFI).

What is the spirit behind the term corporate governance? Corporate governance is the acceptance by management of the inalienable rights of shareholders as the true owners of the corporation and of their own role as trustees on behalf of the shareholders. It deals with conduction of the affairs of a company such that there is fairness, efficiency and transparent administration to all stakeholders as well as strives to meet certain well defined, written objectives. In this regard, the management needs to prevent asymmetry of benefits between various sections of shareholders, especially between the owner- managers and the rest of the shareholders.

It is about commitment to values, about ethical business conduct and about making a distinction between personal and corporate funds in the management of a company. Ethical dilemmas arise from conflicting interests of the parties involved. In this regard, managers make decisions based on a set of principles influenced by the values, context and culture of the organization. It harmonizes the need for a company to strike a balance at all times between the need to enhance shareholders' wealth whilst not in any way being detrimental to the interests of the other stakeholders in the company. The importance of corporate governance has received emphasis in recent times since poor governance and weak internal controls have been associated with major corporate failures (Padmanahban 2011:11). It has also been asserted that intensive governance structure not only enhance the safety and financial strength of the institutions critical for the overall strength of the corporate but foreign investments on which economic growth is built upon. Furthermore, its objective is to generate an environment of trust and confidence amongst those having competing and conflicting interests.

It assumes a 3-tier responsibility i.e.

Political Responsibilities: abiding by legitimate law; respect for the system of rights and the principles of constitutional state.

Social Responsibilities: The corporate ethical responsibilities, towards the social framework of which the co, itself is an integral part.

Economic Responsibilities: maximizing shareholders value by depicting business ethics and enhancing corporate awareness of the environmental and societal interest of the communities, within which they operate.

Historical Development of Corporate Governance in Nigeria.

The history of corporate governance in Nigeria can be said to be convoluted, nonetheless, cannot be divorced from Company Law. Prior to the time the expression "corporate governance" became popular, Company Law recognised and still recognises two organs of a company: the board of directors and the company in general meeting. Corporate governance as a concept merely stressed the greater focus that should be paid on how a company should be run by those put in charge of the company's affairs. The prominence of board of directors in corporate governance is evident in model definitions of corporate governance which in a nutshell regards corporate governance as the processes and structures by which the business and affairs of an institution are directed and managed in order to improve long-term shareholder value by enhancing corporate performance and accountability, while taking into account the interest of other stakeholders. 
Before 1990, the principal Company Law statute in Nigeria was the Companies Act 1968. This enactment was a comprehensive legislation modelled after the Companies Act 1948 of the United Kingdom. It contained elaborate provisions regarding the running of companies in relation to the roles of the board of directors and the members in general meeting. As a result of numerous limitations and criticisms from stakeholders, the Companies Act 1968 was repealed and replaced in 1990 by the then Companies and Allied Matters Decree No, 1 of 1990. With some minor modifications over the years, this statute which is now known as the Companies and Allied Matters Act, Cap. C20, Laws of the Federation of Nigeria 2004, is the principal statute regulating companies in Nigeria.

However, after the coming into force of the statute, some corporate challenges around the world brought the issue of corporate governance to the fore. Consequently, some countries started review their corporate governance practices. This resulted in some countries issuing corporate governance codes to address issues neither specifically nor sufficiently addressed by their respective company legislation.

In the case of Nigeria, its foremost formal corporate governance code could be traced to the Code of Corporate Governance for Banks and Other Financial Institutions in Nigeria which was issued by the Bankers' Committee in August 2003. This Code was the outcome of the work of the Bankers' Committee's Sub-Committee on Corporate Governance. It was initiated in response to the financial crisis in Nigeria in the early 1990s and in the realisation that poor corporate governance was one of the major factors in virtually all known instances of financial sector distress. As is evident from its nomenclature, the Code was applicable to all banks and other financial institutions operating in Nigeria at the time it was issued. Its major weakness was that it was not issued by a regulator having been issued by a voluntary association of the Chief Executives of the banks in Nigeria, otherwise known as Bankers' Committee.

The Code was predicated on 11 Principles. These are:

Responsibilities of the Board of Directors, Structure of the board of Directors, The Chairman and the Chief Executive Officer, Appointments to the Board, Proceedings of the Board of Directors, Directors' Remuneration, Board Performance Assessment, Risk Management, Financial Disclosure, Relations with shareholders, and Audit Committee.

In spite of the comprehensive provisions of the Code, it did not make much impact. A major factor that could have occasioned this was the issuance of the Code of Best Practices on Corporate Governance in Nigeria by the Securities and Exchange Commission in October 2003, about two months after the issuance of the Code.

The Code of Best Practices on Corporate Governance in Nigeria (2003 SEC Code) issued by the Securities and Exchange Commission in 2003 greatly impacted the corporate governance scene in Nigeria. In the first place, it was the first corporate governance code to be issued by any regulator in Nigeria. Secondly, it was applicable to all public companies registered in Nigeria.

After the coming into force of the 2003 SEC Code, there were numerous changes in the corporate world. Quite rapidly, the provisions of the 2003 SEC Code became inadequate to address the new developments in the corporate scene; yet no amendment to it was forthcoming from the Securities and Exchange Commission. This oversight in amending the 2003 SEC Code to bring its provisions up to date with current realities resulted in some regulators of specific sectors issuing industry-specific corporate governance codes which not only took into account the current situations when those codes were made, but they also contained provisions on some matters peculiar to their respective sectors. 
In 2006, the Central Bank of Nigeria issued its Code of Corporate Governance for Banks in Nigeria Post-Consolidation (2006 CBN Code). Compliance with the provisions of this Code is mandatory for all banks operating Nigeria. Essentially, the Code which was issued following the consolidation of Nigerian banks in 2005 was meant to address the identified weaknesses in corporate governance of banks in Nigeria and to resolve the challenges of corporate governance which are bound to occur post-consolidation.

In 2008, following the reforms in the pension sector which gave rise to greater private sector involvement in pension fund management, the National Pension Commission (PENCOM) issued the Code of Corporate Governance for Licensed Pension Operators (2008 PENCOM Code). The 2008 PENCOM Code sets out rules to guide pension fund administrators (including closed pension fund administrators) and pension fund custodians on the structures and processes to be used towards achieving optimal governance processes.

The third regulator to issue an industry-specific corporate governance code is the National Insurance Commission (NAICOM). In 2009, it issued the Code of Good Corporate Governance for the Insurance Industry in Nigeria (2009 NAICOM Code). The 2009 NAICOM Code which was effective on $1^{\text {st }}$ March 2009 is mandatory for all insurance and reinsurance companies under the regulatory supervision of the NAICOM. It The recognised the following as basic principles of good corporate governance: a proactive, responsible, responsive, accountable and committed Board/Management; definite management succession plan; culture of compliance with rules and regulations; good knowledge about business and insurance matters with requisite experience; disclosure and transparency; and effective exercise of shareholders' rights.

The three industry-specific corporate governance codes discussed above addressed corporate governance issues peculiar to the respective sectors at the time of their issuance which the 2003 SEC Code did not address. Furthermore, the 2003 SEC Code lacked adequate provisions on other contemporary corporate governance issues. These include independent directors; critical board committees in relation to corporate governance; directors' appointment, tenure, remuneration and evaluation; ensuring the independence of the external auditors; whistle-blowing procedures; sustainability issues; and general disclosure and transparency issues. Thus, on $1^{\text {st }}$ April 2011, the Securities and Exchange Commission issued the Code of Corporate Governance (2011 sec Code) in Nigeria which replaced the 2003 SEC Code. Being the minimum standards for public companies it has been adjudged to be quite comprehensive. Nevertheless, it still contains some flaws. Interestingly, a few months after the 2011 SEC Code became operational the Financial Reporting Council of Nigeria Act 2011 was enacted by the Federal government. This statute has far-reaching provisions regarding the operation of companies in Nigeria. One of the areas the Financial Reporting Council of Nigeria was given express jurisdiction over is corporate governance. Accordingly, sections 23(g) and 45 provide for the establishment of a Directorate of Corporate Governance for the Financial Reporting Council of Nigeria. Sections 50 and 51 stipulate the objectives and functions of the Directorate of Corporate Governance of the Financial Reporting Council of Nigeria to be the following: to develop principles and practices of corporate governance; promote the highest standards of corporate governance; promote public awareness about corporate governance principles and practices; act as the national coordinating body responsible for all matters pertaining to corporate governance; promote sound financial reporting and accountability based on true and fair financial statements duly audited by competent independent Auditors; encourage sound systems of internal control to safeguard stakeholders' investment and assets of public interest entities; and ensure that audit 
committees of public interest entities keep under review the scope of the audit and its cost effectiveness, the independence and objectivity of the auditors.

The Financial Reporting Council of Nigeria last year set up a committee to bring out unified code to replace the existing codes (by 4 bodies) in place. The committee recently submitted a draft document which will be subjected to public hearing to allow public input and the document would be exposed on the agency's website for the interest of the public for the interest of the public for a period of 90 days. This National Code of Corporate Governance which will contain stiff penalties/fines for varying infractions on the part of corporation or executives is expected to effective $1^{\text {st }}$ January, 2014(www.corporategovernancereport.com).

Commonly Accepted Principles of Corporate Governance

Singhal (2011) and Garg etal (2011) identified five recognized and accepted principles of Corporate Governance as:

(a) Rights and equitable treatment of shareholders: Organizations should respect the rights of shareholders and help shareholders to exercise those rights. They can help shareholders exercise their rights by effectively communicating information that is understandable and accessible and encouraging shareholders to participate in general meetings.

(b) Interests of other stakeholders: Organizations should recognize that they have legal and other obligations to all legitimate stakeholders.

(c) Role and responsibilities of the board: The board needs a range of skills and understanding to be able to deal with various business issues and have the ability to review and challenge management performance. It needs to be of sufficient size and have an appropriate level of commitment to fulfill its responsibilities and duties. There are issues about the appropriate mix of executive and non-executive directors.

(d) Integrity and ethical behavior: Ethical and responsible decision making is not only important for public relations, but it is also a necessary element in risk management and avoiding lawsuits. Organizations should develop a code of conduct for their directors and executives that promotes ethical and responsible decision making.

(e) Disclosure and transparency: Organizations should clarify and make publicly known the roles and responsibilities of board and management to provide shareholders with a level of accountability. They should also implement procedures to independently verify and safeguard the integrity of the company's financial reporting.

Issues Involving Corporate Governance Principles include:

Internal controls and internal auditors. The independence of the entity's external auditors and the quality of their audits. Oversight and management of risk. Oversight of the preparation of the entity's financial statements. Review of the compensation arrangements for the chief executive officer and other senior executives. The resources made available to directors in carrying out their duties. The way in which individuals are nominated for positions on the board. Dividend policy.

Corporate governance mechanisms and controls are designed to reduce the inefficiencies that arise from moral hazard and adverse selection. For example, to monitor managers' behaviour, an independent third party (the external auditor) attests the accuracy of information provided by management to investors. An ideal control system should regulate both motivation and ability.

Internal corporate governance controls monitor activities and then take corrective action to accomplish organizational goals. Examples include:

Monitoring by the board of directors: The board of directors, with its legal authority to hire, fire and compensate top management, safeguards invested capital. Regular board meetings allow potential problems to be identified, discussed and avoided. Executive directors 
possess superior knowledge of the decision-making process and therefore evaluate top management on the basis of the quality of its decisions that lead to financial performance outcomes.

Internal control procedures and internal auditors: Internal control procedures are policies implemented by an entity's board of directors, audit committee, management, and other personnel to provide reasonable assurance of the entity achieving its objectives related to reliable financial reporting, operating efficiency, and compliance with laws and regulations. Balance of power: The simplest balance of power is very common; require that the President be a different person from the Treasurer. This application of separation of power is further developed in companies where separate divisions check and balance each other's actions.

Remuneration: Performance - based remuneration is designed to relate some proportion of salary to individual performance. It may be in the form of cash or non-cash payments such as shares and share options, superannuation or other benefits.

External corporate governance controls encompass the controls external stakeholders exercise over the organization. Examples include: Competition, Debt covenants, Demand for and assessment of performance information (especially financial statements), Government regulations, Managerial labour market, Media pressure, Elements of Corporate Governance.

Various key aspects and elements are interlocked to ensure the existence of good Corporate Government in any company. Suman etal (2011) identified element of Corporate Governance to include:

Regulatory boards - the back bone of the whole system. Boards of director and CEO One of the major elements that play a great role in finalizing company's strategy, policies and ensure the accountability of the organization. Management, Share holders, Auditors, Others suppliers, employees, creditors, customers, community at large. Of these elements, the three key constituents of corporate governance are:

The Board of Directors, The shareholders and The Management

The pivotal role in any system of corporate governance is performed by THE BOARD OF DIRECTORS. It is accountable to the stakeholders and directs and controls and management. It stewards the company, sets its strategic aim and financial goals and oversees their implementation, puts in place adequate internal controls and periodically reports the activities and progress of the company in the company in a transparent manner to all the stakeholders.

THE SHAREHOLDERS role is to appoint the directors and the auditors and to hold the board accountable for the proper governance of the company by requiring the board to provide tem periodically with the requisite information in a transparent fashion, of the activities and progress of the company.

The responsibility of THE MANAGEMENT is to undertake the management of the company in terms of the direction provided by the board, to ensure the operation of internal controls and to provide information to the board on a timely basis and in a transparent manner to enable the board to monitor the accountability of management to it. Need, Importance and Objectives of Corporate Governance.

In order to overcome the under noted serious concerns within the business community, there is a need to introduce a system of corporate governance that will ensure the transparency, integrity and accountability of Management including non-executive directors. Concentration of greater financial power and authority in a lesser number of individuals. Violations of foreign exchange rules and regulations. Large-scale diversion of funds to associate companies and risky ventures. Unfocussed business decisions leading to losses. Preferential allotment of shares to promoters at low prices. Exploited the weaknesses in the 
Accounting standards to inflate profits and understate liabilities. Frequent changes in Board structures. Spinning off profitable business operations to subsidiary companies. Charging of royalty for use of brand name by the parent company by leading companies. Good corporate governance practices also enable Management to allocate resources more efficiently which increases the likelihood that investors will obtain a higher rate of return on their investment. Good corporate governance practices ensure.

Adequate disclosures and effective decision making to achieve corporate objectives; Transparency in business transactions; Statutory and legal compliances; Protection of shareholder interests; Commitment to values and ethical conduct of business. Long-term survival of the companies. Good corporate governance is very important because of its role in attracting foreign investment. The extent of foreign investment, in turn, shapes the prospects for economic growth for many developing countries. Corporate governance can play a role in reducing corruption, and decreased corruption significantly enhances a country's development prospects. The aim of "Good Corporate Governance" is to ensure commitment of the board in managing the company in a transparent manner for maximizing long-term value of the company for its shareholders and all other partners.

Attracting Foreign Investment through Corporate Governance

1. Investors usually consider two aspects before making any investment (a) rate of return on invested capital (b) risk associated with investment. Companies responding positively with corporate Governance enjoy better goodwill and attract investment of foreign capital in the world (Vijay and Gaurav 2011).

2. Good Corporate Governance practice increase transparency accountability, enforceability in the market place. It equally built confidence among stakeholders.

3. It ensures country's long term success on financial platform as well on social responsibilities platform.

4. It boosts or establishes investor confidence in the economy (Izora 2013). The credibility offered by good corporate governance procedures also helps to maintain the confidence of investors both foreign and domestics, to attract more long term capital.

5. Corporate Governance help create a clement environment for investors in the country.

6. Also strengthen the investors from sudden crisis.

7. Effective Corporate Governance reduces perceived risks which reduces cost of capital and enhances quick and better decisions, which ultimately improves the bottom line of the corporate.

8. By raising the bar in the public and private sectors and with stiff penalties for executives or corporation, Corporate Governance attracts foreign direct investment inflows, and enhances Nigeria's competiveness and international perception.

9. Sound Corporate Governance is a back bone of those countries which strongly rely on stock market to raise foreign capital. As Nigeria is the emerging nation in this sector.

10. Emergence of Institutional Investors (pension funds, MF, hedge funds, exchange traded funds, other investors groups, insurance companies, banks, brokers and other financial institutions) has brought professional diligence in investment sector.

As a big number of individuals invest their money indirectly through these Institutional Investors we can say, the majority of investment is described as "Institutional Investors". It also plays a great role in enrichment of corporate governance. 


\section{CONCLUSION}

Good corporate governance may not be the engine of economic growth, but it is essential for the proper functioning of the engine. The investors both national and international would be loyal wholeheartedly must in Nigerian companies if they follow all the standards of corporate governance practices. With the privatization and commercialization of government companies in Nigeria, the size of corporations are becoming much bigger and accordingly the expectation of various stakeholders are also increasing which can only be quenched by good corporate governance

\section{References}

[1] Cadbury Andrain, Chairman (1992.) Report on the Financial Aspects Corporate Governance.

[2] Companies and Allied matters Act, Cap C20 2004.

[3] Garg Sanjeer and Garg Anuj, (2011) Corporate Governance - A Changing Scenario. A.P.H Publishing Corporation New Delhi, India.

[4] http:www.Corporate Governance report.com/auditing-policies/Nigeria Nigeria to implement corporate governance code by 2014 Retrieved on 20130829

[5] Izora Chike, (2013): Nigeria: National Corporate Governance Code Takes Effect January 2014. www:// allafrica.com/stories $20130729290631 \mathrm{htm} .1$

[6] Nat OFO, (2013): Historical Development of Corporate Governance in Nigeria. http:the coporateprof.com/blog/2013/01/07 Retrieved on 20130829.

[7] Padmanahban Aishwarya, (2011): Corporate Governance in Insurance Companies. A.P.H Publishing Corporation New Delhi, India.

[8] Singhal Sushil, (2011): Create a Better India through Corporate Governance. A.P.H Publishing Corporation New Delhi, India.

[9] Sumar Bhatia and Vipin Shurma, (2011): Corporate Governance and its dimension. A.P.H Publishing Corporation New Delhi, India.

[10] Vijay Chhabra and Gaurav Vij, (2011): Corporate Governance in Telcom Sector. A.P.H Publishing Corporation New Delhi, India.

[11] Tomáš Hes, Anna Poledňáková, International Letters of Social and Humanistic Sciences 2 (2013) 18-31.

[12] Mohsen Mehrara, Masoumeh zirak, International Letters of Social and Humanistic Sciences 2 (2013) 32-38.

[13] Taiwo Adewale Muritala, Ismail O. Fasanya, International Letters of Social and Humanistic Sciences 2 (2013) 39-50.

[14] Borowski A., International Letters of Social and Humanistic Sciences 3 (2013) 46-53.

[15] Borowski A., International Letters of Social and Humanistic Sciences 3 (2013) 69-74.

[16] Donovan A. McFarlane, International Letters of Social and Humanistic Sciences 4 (2013) 35-44.

[17] Rajesh K. Yadav, Nishant Dabhade, International Letters of Social and Humanistic Sciences 4 (2013) 49-69.

[18] Borowski A., International Letters of Social and Humanistic Sciences 4 (2013) 70-74. 
[19] Paul Bukuluki, International Letters of Social and Humanistic Sciences 5 (2013) 27-44.

[20] Mohsen Mehrara, Maysam Musai, International Letters of Social and Humanistic Sciences 5 (2013) 55-62.

[21] Debiprasad Mukherjee, International Letters of Social and Humanistic Sciences 6 (2013) 41-48.

[22] Tomáš Hes, Alena Neradová, Karel Srnec, International Letters of Social and Humanistic Sciences 7 (2013) 55-75.

[23] Kinga Dziwańska, International Letters of Social and Humanistic Sciences 7 (2013) 96-112.

[24] Borowski A., International Letters of Social and Humanistic Sciences 7 (2013) 113-118.

[25] Mohsen Mehrara, Maysam Musai, International Letters of Social and Humanistic Sciences 8 (2013) 1-7.

[26] Tittenbrun J., International Letters of Social and Humanistic Sciences 11 (2013) 10-34.

[27] Mohsen Mehrara, Hamid Abrishami, Mostafa Boroujli, Mahan Amin, International Letters of Social and Humanistic Sciences 11 (2013) 76-83.

[28] Borowski A., International Letters of Social and Humanistic Sciences 11 (2013) 100-105.

[29] Morteza Amani, Mahmood Goodarzi, Hamze Ahamadian, International Letters of Social and Humanistic Sciences 1 (2014) 7-13.

[30] Seyed Mohammad Marandi, Hossein Pirnajmuddin, International Letters of Social and Humanistic Sciences 1 (2014) 14-27.

[31] Elias Olukorede Wahab, Chioma Joan Ikebudu, International Letters of Social and Humanistic Sciences 1 (2014) 28-42.

[32] Bahram Meihami, Zeinab Varmaghani, Hussein Meihami, International Letters of Social and Humanistic Sciences 1 (2014) 43-5.

[33] Francis Briggs, Elizabeth Desmond, International Letters of Social and Humanistic Sciences 1 (2014) 71-80.

[34] Liverpool E. Onyije, Jacinta A. Opara, International Letters of Social and Humanistic Sciences 1 (2014) 81-87

[35] Sele Sylvester Ebisin, International Letters of Social and Humanistic Sciences 2 (2014) $1-9$.

[36] Tittenbrun J., International Letters of Social and Humanistic Sciences 2 (2014) 20-40.

[37] Borowski A., International Letters of Social and Humanistic Sciences 2 (2014) 110-121.

[38] Pawa Tersoo, International Letters of Social and Humanistic Sciences 3 (2014) 26-36.

[39] Rabi'u Muhammad Ishaq, International Letters of Social and Humanistic Sciences 3 (2014) 37-44.

[40] Adoga James Ada, International Letters of Social and Humanistic Sciences 3 (2014) 45-52.

[41] Bahram Meihami, Hussein Meihami, International Letters of Social and Humanistic Sciences 3 (2014) 80-91.

[42] Kabiru Ibrahim Yankuzo, International Letters of Social and Humanistic Sciences 4 (2014) 1-8.

[43] Onyike Maggaret Odu, International Letters of Social and Humanistic Sciences 4 (2014) 31-39.

[44] Uloma Charity Oguzor, International Letters of Social and Humanistic Sciences 4 (2014) 97-104. 
[45] Okezie A. Ihugba, Alex Odii, A. C. Njoku, International Letters of Social and Humanistic Sciences 5 (2014) 21-34.

[46] Okezie A. Ihugba, Bankoli Bankong, N. C. Ebomuche, International Letters of Social and Humanistic Sciences 5 (2014) 92-113.

[47] Borowski A., International Letters of Social and Humanistic Sciences 6 (2013) 86-90. 